\title{
UNIQUENESS THEOREMS ON FUNCTIONAL INEQUALITIES CONCERNING CUBIC-QUADRATIC-ADDITIVE EQUATION
}

\author{
YAnG-Hi LeE, SoOn-Mo Jung And Michael Th. RASsias
}

Abstract. We prove uniqueness theorems concerning the functional inequalities in connection with an $n$-dimensional cubic-quadratic-additive equation $\sum_{i=1}^{m} c_{i} f\left(a_{i 1} x_{1}+a_{i 2} x_{2}+\cdots+a_{i n} x_{n}\right)=0$ by applying the direct method.

Mathematics subject classification (2010): 39B82, 39B52.

Keywords and phrases: Functional inequality, functional equation, generalized Hyers-Ulam stability, $n$-dimensional cubic-quadratic-additive functional equation, direct method.

\section{REFERENCES}

[1] S. CzerwiK, Functional Equations and Inequalities in Several Variables, World Sci. Publ., Singapore, 2002.

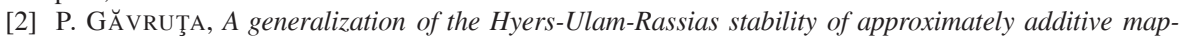
pings, J. Math. Anal. Appl. 184 (1994), 431-436.

[3] L. GĂVRUŢA AND P. GĂVRUŢA, On a problem of John M. Rassias concerning the stability in Ulam sense of Euler-Lagrange equation, in: Functional Equations, Diferrence Inequalities and Ulam Stability Notions (J. M. Rassias ed.), Nova Science Publishers, 2010 (pp. 47-53).

[4] A. GILANYI, Hyers-Ulam stability of monomial functional equations on a general domain, Proc. Natl. Sci. USA 96 (1999), 10588-10590.

[5] M. E. Gordji, S. K. Gharetapeh, J. M. Rassias and S. Zolfaghari, Solution and stability of a mixed type additive, quadratic, and cubic functional equation, Adv. Difference Equ. 2009 (2009), Article ID 826130, 17 pages.

[6] M. E. GoRdJI AND H. KHODAEI, Solution and stability of generalized mixed type cubic, quadratic and additive functional equation in quasi-Banach spaces, Nonlinear Anal. 71 (2009), 5629-5643.

[7] D. H. HYERS, On the stability of the linear functional equation, Proc. Natl. Acad. Sci. USA 27 (1941), 222-224.

[8] S.-M. Jung, Hyers-Ulam-Rassias Stability of Functional Equations in Nonlinear Analysis, Springer Optimization and Its Applications, vol. 48, Springer, New York, 2011.

[9] S.-M. Jung, D. Popa AND M. Th. RAssias, On the stability of the linear functional equation in a single variable on complete metric groups, J. Global Optim. 59 (2014), no. 1, 165-171.

[10] S.-M. JUNG AND M. TH. RAssias, A linear functional equation of third order associated with the Fibonacci numbers, Abstr. Appl. Anal. 2014 (2014), Article ID 137468, 7 pages.

[11] S.-M. Jung, M. Th. RASSIAS AND C. Mortici, On a functional equation of trigonometric type, Appl. Math. Comput. 252 (2015), 294-303.

[12] PL. Kannappan, Functional Equations and Inequalities with Applications, Springer, New York, 2009.

[13] Y.-H. LEE, On the generalized Hyers-Ulam stability of the generalized polynomial function of degree 3, Tamsui Oxf. J. Math. Sci. 24 (4) (2008), 429-444.

[14] Y.-H. LEE AND S.-M. JunG, General uniqueness theorem concerning the stability of additive, quadratic, and cubic functional equations, Adv. Difference Equ. 2016 (2016), Article no. 75, 12 pages.

[15] C. Mortici, M. TH. Rassias AND S.-M. JUnG, On the stability of a functional equation associated with the Fibonacci numbers, Abstr. Appl. Anal. 2014 (2014), Article ID 546046, 6 pages. 
[16] C. PARK, A fixed point approach to the Fuzzy stability of an additive-quadratic-cubic functional equation, Fixed Point Theory Appl. 2009 (2009), Article ID 918785, 24 pages.

[17] Th. M. Rassias, On the stability of the linear mapping in Banach spaces, Proc. Amer. Math. Soc. 72 (1978), 297-300.

[18] S. M. Ulam, A Collection of Mathematical Problems, Interscience Publ., New York, 1960. 